$10-1-2018$

\title{
An examination of state and local government pension underfunding -Implications and guidance for governance and regulation
}

\author{
Craig L. Foltin \\ Cleveland State University, I.foltin@csuohio.edu
}

Follow this and additional works at: https://engagedscholarship.csuohio.edu/bus_facpub

Part of the Accounting Commons

How does access to this work benefit you? Let us know!

Publisher's Statement

This is the author's version of a work that was accepted for publication in Research in Accounting Regulation. Changes resulting from the publishing process, such as peer review, editing, corrections, structural formatting, and other quality control mechanisms may not be reflected in this document. Changes may have been made to this work since it was submitted for publication. A definitive version was subsequently published in Research in Accounting Regulation, 30, 2, (2018), 10.1016/j.racreg.2018.09.003.

\section{Recommended Citation}

Foltin, Craig L., "An examination of state and local government pension underfunding -Implications and guidance for governance and regulation" (2018). Business Faculty Publications. 298.

https://engagedscholarship.csuohio.edu/bus_facpub/298

This Article is brought to you for free and open access by the Monte Ahuja College of Business at EngagedScholarship@CSU. It has been accepted for inclusion in Business Faculty Publications by an authorized administrator of EngagedScholarship@CSU. For more information, please contact library.es@csuohio.edu. 


\title{
An examination of state and local government pension underfunding - Implications and guidance for governance and regulation
}

\author{
Craig Foltin
}

\section{A R T I C L E I N F O}

Keywords:

Public pensions

GASB

State budgets

Pension policy

Bodrd governance

\begin{abstract}
A B S T R A C T
State and local government pension underfunding has become a major focus of public policy debate due in large part to recent Governmental Accounting Standards Board (GASB) actions that have brought national attention to the issue. The extent of these plans underfunding has been debated, along with the necessity for state government intervention and the level of regulatory actions that should be enacted by state legislatures. State and local public pension plans do not fall under the enumerated powers of the federal government in the Constitution and are therefore left to each individual state to regulate. The amount of plan underfunding and enacted public policy by state varies greatly. Additionally, in contrast to numerous state balanced-budget laws, legal directives for fully funding public pensions are virtually nonexistent. This paper analyzes the state and local public pension crisis, examines current and long-term risk, studies public employee fiscal conditions, considers the societal impacts of these plans, considers the strengths and weakness of pension plan types, recommends public policy and regulation, and offers strategies for managers, board members, and public officials to adopt.
\end{abstract}

(C) 2018 Elsevier Ltd. All rights reserved.

\section{Introduction}

Public pension plans date back to the 1870 s when New York City police officers were granted lifetime payments at age 55 after 21 years of service. In comparison, the first private sector plan was established in 1875 by the American Express Company. This plan created the framework for other pension plans to follow by including retirement age, longevity, and percentage of annual salary as a basis for providing retirement income. In their case, it was 60 years of age, with 20 years of continuous service, providing $50 \%$ of income level at retirement (Stone, 1984). In 1911, Massachusetts became the first state to create a pension plan for all general state employees (NCPERS, 2003). The growth of public plans continued through the 1960 's when virtually all public service employees were covered by some type of public retirement benefits. These payments generally came in the form of defined benefits (DB) that guaranteed a fixed income to the retired employee for life. This is in contrast to the newer form of pension plans called defined contribution (DC) which are $401(\mathrm{k})$ type plans where employees and employers contribute to employee-controlled investment accounts.

For nearly a century and a half, there has been little concern for or discussion regarding the solvency of public DB pension plans and payments to retirees have continued to flow. Over the years, many of these plans have not been managed properly, and now have large future pension liabilities for retirees without the assets to cover them. Recently, the GASB has required that any unfunded pension liabilities be reported on state and local government balance sheets and the expected rate of return used in calculating the liability.

These new requirements bring significant transformation to determining and reporting pension liabilities. It has been shown that bond investors have already adjusted and taken into account the unfunded pension liability in both the private sector (Shaw, 2008) and in the public sector (Foltin et al., 2017). Therefore, the bigger impact of these standards may be the heightened awareness GASB has brought to the public regarding underfunding and liability amount. Discount rate, assumptions regarding future returns, amount of benefits, and investment decisions have become a matter of public debate. Policy change and media coverage have greatly increased since GASB focused attention on the issue especially with the most troubled pension funds.

Several pension funds across the country experienced much publicized troubles with their plans. State plans in California, Illinois, New Jersey, and Kentucky, and municipal plans like Chicago, Detroit, and Dallas, have been forced to take action due to low funding levels. These events along with GASB's actions have turned a spotlight on the funding of public pensions. Fund management, board inaction, elected official indecisiveness, taxpayer funding, 


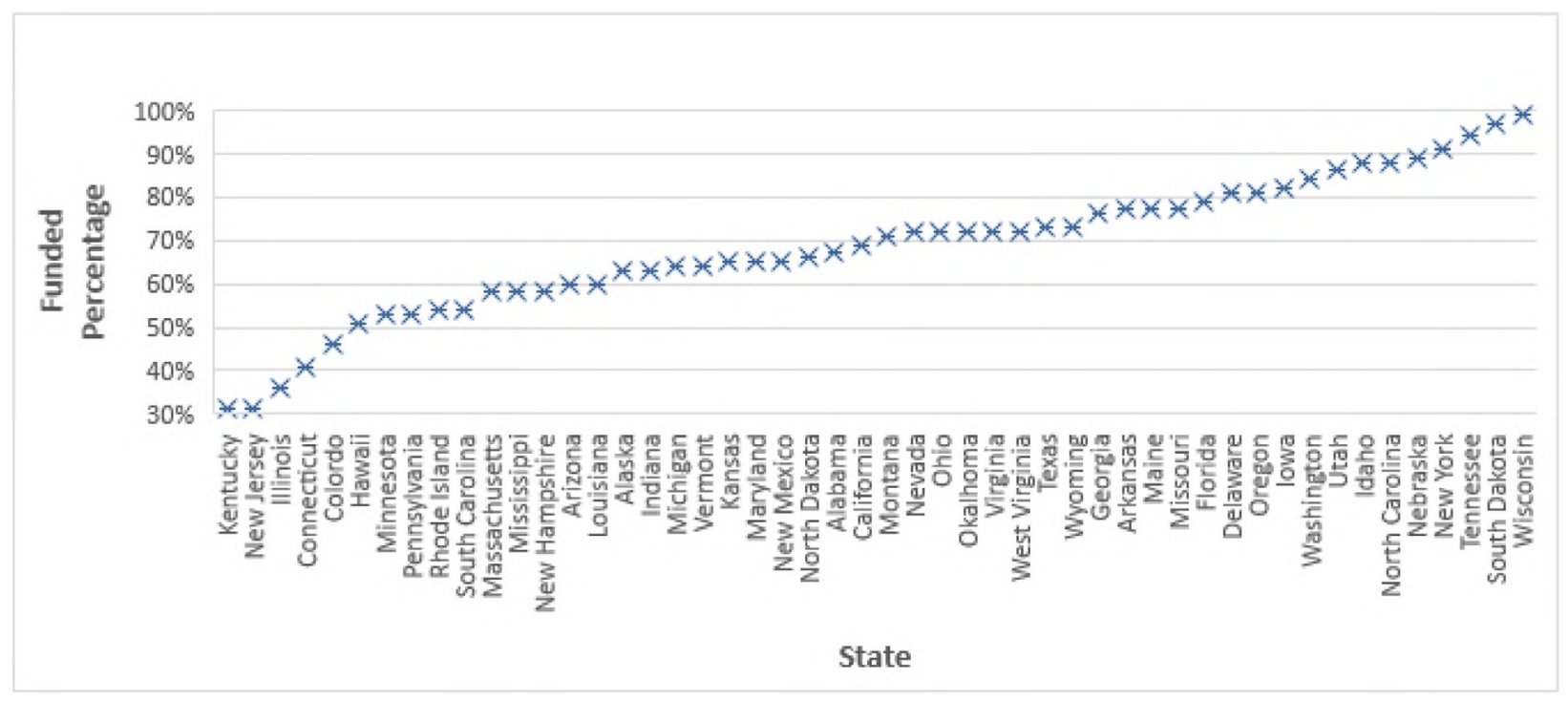

Exhibit 1. Funded Percentage Pldn Assets in Proportion to Accrued Pension Lidbility. Source: Pew Charitable Trusts (2018).

expected returns, investment decisions, and benefits to employees have all come under scrutiny. Actions to remedy these issues have so far largely dealt with benefit cuts by altering the mechanics of the plans, such as reducing cost of living adjustments (COLA), cutting benefit amounts, increasing retirement age, and even moving to DC plans (Foltin et al., 2018). However, the heart of the problem - policy, regulation, and governance - has remained untouched and virtually unmentioned.

\section{Pension plan underfunding}

Public pension underfunding amounts vary depending on the methodology used in calculating liabilities. Pew Charitable Trusts (Craig, 2018) estimates the deficit at $\$ 1.4$ trillion based upon Comprehensive Annual Financial Reports, actuarial reports, and public financial statements. In contrast, Stanford University's Hoover Institution study (Rauh, 2017) places the amount at $\$ 3.8$ trillion.

The difference in estimates is attributable to the long-range projected rate of return. It has been shown that discount rates can be manipulated to meet the needs of an entity through lowering the liability on the balance sheet or lowering pension expense on the income statement (Fried, Davis-Friday, \& Davis, 2014). Pew used the actual rates of return applied by the pension funds: a $7.5 \%$ average rate. The Stanford study uses a weighted average, plan-byplan rate tied to the treasury yield which generates a $2.7 \%$ annual projected rate of return. The most realistic discount rate and actual deficit most likely lies somewhere between these two figures and will continue to provide debate in state legislatures and on a national level.

Private sector research has studied the use of International Accounting Standards in which the long-term expected rate of return on pension plan assets has been eliminated. However, this has shown to have a great impact on firms with "extreme" levels of funded status (Bauman \& Shaw, 2016). Using the Pew Data, Exhibit 1 lists all the states and their funded percentages.

Under both the Pew and Hoover Institute methodologies, pension deficits have been rising and funded percentages are decreasing. The 2018 Pew study shows 44 of 50 states experienced a decrease in their funded pension percentage, with Wisconsin being the only state with any improvement at 1\%. Although 2017 numbers are expected to improve, most long-term forecasts predict continued strain on public pension funds (Foltin et.al, 2018).

\section{Pension reforms and fiscal stability}

The National Association of State Retirement Administrators (NARSA) (Brainard \& Brown, 2016) reports that in the last decade, every state has passed pension reform legislation, with most legislative changes having a negative impact on the level of employee benefits awarded. Employees are now required to pay more than they have in the past. Forty states lowered benefits by either changing formulas used to calculate benefits, reducing COLA, and/or requiring employees to work longer. Increased contributions and cuts in benefits are even more dramatic for newly hired employees.

Five states: Michigan, Rhode Island, Tennessee, Utah, and Virginia, have created combination DB/DC plans. Kansas and Kentucky created cash balance plans for new employees where the employer puts in a percentage of employee salary and provides a nominal interest rate. Although cash balance plans are still considered DB plans, they are a big step closer to DC plans and another shift away from traditional DB plans. Arizona and Oklahoma closed their traditional DB plans for all new hires with DC being the only option. Many of these pension changes have been declared successful, have received praise from public officials, and have indeed made strides toward reducing governmental pension underfunding. The Manhattan Institute (DiSalvo, 2015) and the Brookings Institute (McGuinn, 2014) even use some of the above-mentioned states as best practice case studies for other governments seeking to reduce pension deficits.

Consensus by policymakers does not necessarily demonstrate success. Crisis has brought opportunity to make pension benefit cuts. Wong (2016) writes that keeping politics out of pension fund decisions will benefit fund performance. Whether politics or genuine concern for the financial stability of pension funds is the driving force behind policy changes, dramatic change is occurring. After reviewing pension reforms enacted by states, actions by public officials to increase employee contributions, cut benefits, and shift toward DC plans are having a positive impact on the stability of funds - at the very least, the decline is less. 


\begin{tabular}{|l|c|l|}
\hline \multicolumn{1}{|c|}{ Company } & Amount & Year \\
\hline Caterpillar & $\$ 16.5$ & 2009 \\
\hline Hartford/Neuberger Berman & $\$ 13.9$ & 2009 \\
\hline Bechtel & $\$ 18.5$ & 2010 \\
\hline General Dynamics & $\$ 15.1$ & 2010 \\
\hline Walmart/Merrill Lynch & $\$ 13.5$ & 2011 \\
\hline Kraft & $\$ 9.5$ & 2012 \\
\hline Cigna & $\$ 35$ & 2013 \\
\hline International Paper & $\$ 30$ & 2014 \\
\hline Voya & $\$ 15$ & 2014 \\
\hline Lockheed Martin & $\$ 62$ & 2015 \\
\hline Boeing & $\$ 57$ & 2015 \\
\hline Ameriprise & $\$ 27.5$ & 2015 \\
\hline MassMutual & $\$ 30$ & 2016 \\
\hline TIAA & $\$ 8.9$ & 2017 \\
\hline
\end{tabular}

Exhibit 2. 401(k) Settlements (in millions).

Source: Wilcox Volz and Laermer (2017).

Although the focus has been on solidifying the financial condition of public pension funds, it is still early enough in the process of public pension restructuring for other factors such as employee welfare and societal impact to be taken into account.

\section{Shifting risk - Are employees equipped?}

Most of the focus surrounding the pension crisis is on the financial soundness of the funds and how to fix the underfunding. The employee's ability to manage money and their long-term financial well-being in retirement is often overshadowed by the problem garnering the most attention - the underfunding. The emphasis has been on the liability, not asset management and employee security. The fiscal realities that most public sector American workers are faced with has been largely overlooked.

The University of California Berkley Haas Institute study (Sgouros, 2017) contends that DC plans are not in the best interest of employees or a feasible solution to the looming public employee retirement crisis. The study cites higher administrative costs for DC plans and the difficulty for an individual to successfully save an appropriate amount in a DC plan to live on for the rest of their life. Moreover, the motivation of the private sector toward DC plans is marked by bias and the desire to repurpose capital.

Another related problem is putting this risk and responsibility of saving and high-level investment decision making on the individual employee. Moving investment and mortality risk to employees without sophisticated financial knowledge creates uncertainty and takes away the security of DB plans. Big business or large governments have more expertise to make investment decisions, more influence in dealing with investment managers, and the financial wherewithal to weather a financial crisis.

Merton (2014) predicts a major retirement crisis as baby boomers begin to retire. He argues that DC plans wrongly focus on fund value and return rather than the income needed upon retirement. Merton also asserts it is dangerous and illogical to put complex investment decisions in the hands of individuals with little financial expertise. This thought is supported by Clark et al. (2010) who have shown that older workers are not well informed about company and national retirement plans. The lack of financial literacy of most workers and retirees is certainly a factor that must be considered if retirement plans are to provide individuals with sufficient financial resources in retirement.

In addition, the financial service firms that manage DC plans bring potential vulnerability that could place retirees at risk. For example, the Teachers Insurance and Annuity Corporation (TIAA), the leading retirement investment provider for five million workers and retirees in academic and public service, has recently come under scrutiny for the management of its plans. TIAA manages a trillion dollars in retirement and other assets. Recent lawsuits and whistle-blower complaints by a group of former workers contend that TIAA is pushing customers into investments that do not add value, are not in the employees' best interest, and are promoted to generate higher fees for TIAA rather than for the benefit of members of the plan. Other DC plan managers have also been under fire by members. Thus far, there has been over $\$ 400$ million awarded by various $401(\mathrm{k})$ plans to employees and retirees in lawsuits for conflicts of interest over investment decisions and oversize fees (Wilcox Volz \& Laermer, 2017). Some major litigation awards are shown in Exhibit 2. The lack of profit motive in government-managed DB plans mitigates this additional risk exposure.

Further adding to the retirement plan problem is the fact that most individuals approaching retirement age simply have not saved or invested sufficient resources to live on. The Government Accountability Office (GAO, 2015) found that about half of households age 55 and older have no retirement savings such as a $401(\mathrm{k})$ plan or IRA. This study found from one-third to two-thirds of workers are at risk of falling short of targeted retirement savings. 
Participation rates in private retirement plans are heavily based upon individual economic situations, or the haves vs. the havenots. For example, high-income professional workers participate at a rate that is $44 \%$ higher than those individuals working in the service area (U.S. Bureau of Labor Statistics, 2016).

Another often unnoticed factor in the debate over public sector retirement plans is the fact that many public workers are not eligible for social security. With no source of federal retirement, state and local government workers are even more vulnerable to economic pressures in retirement.

\section{Societal impact}

The impact of depleted public pension plans on society goes beyond what some consider a moral obligation to provide a sustainable income for individuals who have worked their career in the public sector. Drucker (1976) first presented the concept of pension fund socialism. At the time, pension funds owned $25 \%$ of the equity capital of American business and had a strong position in the nation's largest companies. Drucker predicted that by 1985, pension funds would own $50 \%$ of the equity capital of American business. Drucker characterized this ownership of business by workers through pension funds as socialism. However, corporate DB plan funds started their decline around this time, with $78 \%$ of all employees participating in a DB pension fund in 1975 as compared to $27 \%$ participation by 2015 (US Department of Labor, 2018). It is clear that the pension fund socialism theory did not come to fruition and is evidenced by comparing current private pension fund assets of $\$ 1.3$ trillion, and public pension fund assets of nearly $\$ 4$ trillion versus the overall market capitalization of US domestic companies of $\$ 27$ trillion.

With the decrease in members and money comes a weakening of employee influence on corporate America, their boards, and decisions. An individual 401(k) holder loses not only the influence of large public plans, but also loses the power to file lawsuits and the ability to consult with investment managers. Without pension fund representation, shareholder activism of employees is diminished.

Despite the fall of the private sector plans, public pension plans can still carry significant weight. The bigger public pension funds in the country continue to have an impact among institutional investors. Despite declining membership across the country, especially as public-sector unions have come under attack, David Webber (2018), calls public pension funds - organized labor's most potent weapon remaining.

Finally, employees in the U.S. are working longer than they ever have. The United States Bureau of Labor Statistics (Toossi \& Torpey, 2017) reports that workers 55 years of age and over now make up $23 \%$ of the total workforce, up from $13.1 \%$ in 2000 . This number is expected to rise to nearly $25 \%$ by 2020 . Public pension reforms will help perpetuate this trend, as workers are forced to work longer to afford retirement. In addition, there is less opportunity for younger workers since older workers are still in their positions. This extended work life that America's society is implementing is due in large part to the decrease in DB plans and unpreparedness of individuals in DC plans. This is another consideration for public pension reform, especially for those serving in public safety.

\section{Cost versus benefits of defined benefit plans}

As the research cited in the previous two sections demonstrate, it can be argued that public sector employees are ill-equipped to manage DC plans and DB plans are a value to society. However, it can just as easily be claimed that they are an unwarranted financial burden on government budgets and an unfair expense to citizens. Guaranteed retirement benefits for life can be debated as a societal and cultural argument - one of human personal need vs. government economic stability. Issues such as retirement age, amount of benefit, and cost to taxpayers are all valid considerations which have no right or wrong answer. For most Americans who work in the private sector, the debate is all but over. The vast majority of people in the U.S. working in corporate America belong to DC plans. Now the discussion moves to the government sector where the eventual financial drain falls to the taxpayer. Exhibit 3 details the strengths and weaknesses of DB plans.

The advantages of DB plans primarily center around the benefit to the employee, while the disadvantages primarily focus on cost to the employer and the fiscal soundness of the government entity supported by taxpayer dollars.

As the data in this study reveals, most of the changes have trended toward improving the fiscal soundness of the respective governments primarily through reduction of benefits. However, an example of a less common resolution lies in the City of Chicago, where lower employee contributions, cost of living adjustments and lower retirement age were maintained in favor of a nearly $30 \%$ increase in water and sewer rates. This was implemented to fund the distressed city workers pension fund. The strong union structure in Chicago may have played a role in this outcome.

There are some business case arguments that support the concept of DB plans. In the private sector, firms with DB plans had increased book value, earnings and market value after pension disclosure standards were promulgated (Houmes, Boylan, \& Crosby, 2012). This shows not only improved reporting quality, but possibly an intangible value to the firm that maintains DB plans.

Another business case claim in support of DB plans lies with the ability of state and local governments to be competitive in the labor market. A new study shows that recent pension cuts hurt governments' ability to recruit quality workers especially considering that the private sector typically pays higher wages for similar positions (Quinby, Sanzenbacher, \& Aubry, 2018).

Alternately, one cannot ignore the cost of public pensions. These costs as a percentage of state budgets comprise $4.7 \%$ of all state and local government spending (NARSA, 2017). When additional dollars go into pensions, other areas such as parks, education, and social programs lose budgetary funding. When considering addressing the unfunded pension deficit, the impact on the budget is even greater. Depending on what discount rate is used, the percentage of state and local government budgets that it would take to fully fund public pensions could be as much as $20 \%$. The fairness of taxpayers carrying this burden should be considered, especially since these taxpayers predominantly participate in DC plans.

The choices for policymakers are difficult and often influenced by the overall financial prosperity of a state and the political structure as seen in Chicago.

\section{Policy authority and influence}

Each individual state government holds exclusive control over all state and local government pensions. Due to the United States Constitution's Tenth Amendment in the Bill of Rights, (U.S., 1789), the federal government can only exercise those rights specifically granted in the Constitution: "The powers not delegated to the United States by the Constitution, nor prohibited by it to the States, are reserved to the States respectively, or the people." Although the federal government has made some attempts to regulate states in areas such as municipal securities through the Securities and Exchange Commission and by means of self-regulatory agencies such as the Municipal Securities Rulemaking Board, little has been done to penetrate the individual states' control of such issues (Foltin, 2017).

With public pension funds exclusively under state and local government control, they are not covered under the Employee 


\begin{tabular}{|l|l|}
\multicolumn{2}{c}{ Strength } \\
\hline Employee Security & Fiscal cost to the government entity \\
\hline Earlier retirement age for employees & $\begin{array}{l}\text { Losing talent earlier, paying pension } \\
\text { benefits sooner and longer }\end{array}$ \\
\hline $\begin{array}{l}\text { Makes governments more competitive } \\
\text { for hiring talented individuals }\end{array}$ & $\begin{array}{l}\text { Obligation to the entity spans for } \\
\text { decades }\end{array}$ \\
\hline Employee investment risk is reduced & Risk falls to the government \\
\hline $\begin{array}{l}\text { Provides public employees a voice on } \\
\text { corporate operations }\end{array}$ & $\begin{array}{l}\text { Employees do not maintain control of } \\
\text { their investments }\end{array}$ \\
\hline $\begin{array}{l}\text { Promotes stability and reduces } \\
\text { turnover }\end{array}$ & $\begin{array}{l}\text { Longer vesting period for the employee } \\
\text { pension value often lost until vested }\end{array}$ \\
\hline $\begin{array}{l}\text { Government entities financially } \\
\text { stronger and possess better ability to } \\
\text { manage assets }\end{array}$ & $\begin{array}{l}\text { Fosters financial illiteracy for public } \\
\text { employees }\end{array}$ \\
\hline $\begin{array}{l}\text { Less volatility in employee } \\
\text { contributions and distributions }\end{array}$ & Restrictions on withdrawal of funds \\
\hline Less investment and management fees & $\begin{array}{l}\text { Employee autonomy in choosing } \\
\text { investments lost }\end{array}$ \\
\hline Increased transparency & $\begin{array}{l}\text { The liability amounts difficult to explain } \\
\text { and understand }\end{array}$ \\
\hline
\end{tabular}

Exhibit 3. Strengths and Weaknesses of Defined Benefit Pension Plans for Public Employees.

Retirement Income Security Act of 1974, which sets standards required by law for all private sector plans. Similarly, if a publicsector plan runs into severe financial trouble as is happening in many states today, there is no payment assurance for retirees through the Pension Benefit Guaranty Corporation. All regulation and standard setting in regard to management, investing, benefits, actuarial estimates, vesting, and funding is the responsibility of state lawmakers.

\section{State budget policy implications}

State regulation ensuring fully funded pension funds is virtually non-existent. However, most states have formal balanced budget requirements, meaning states must generate sufficient revenue to meet operating expenditures in any given year. Any surpluses can typically be used to help balance a budget. The National Conference of State Legislatures NCSL (2010) reports that 49 states (with Vermont being the only exception) have balanced budget regulations in their state Constitutions or have enacted laws requiring a balanced budget. The National Association of State Budget Officers (NASBO, 2015) reports similar findings. These balanced budget laws may come in the form of the Governor's submitted budget, the legislature passed budget, ending carryover deficit, or combinations of all three.

Some argue that many balanced budget laws are not strong enough. The American Legislative Exchange Council (Eucalitto, 2013) cites tactics used to circumvent balanced budget requirements such as shifting of money from different funds, shifting payment dates to the following year, using debt, and using unrealistic expected rates of return on pension payments. Barrett and Green (2011) assert that states often use adjusted forecasts and loopholes as additional methods to evade the laws. The Institute for Truth in Accounting (2009) has also demonstrated that states use accounting to circumvent balanced budget legislation. They performed a review of state annual reports that show that the majority of states budgets are not balanced. Current financial data also supports the argument that states are not truly complying with balanced budget requirements and there is a large variance in the fiscal health of the states. A Mercatus Center at George Mason University Research study (Norcross and Gonzlaez, 2017) ranks the fiscal health of states and shows many states are dealing with serious budgetary problems. The Center extrapolated data from the audited financial reports of all 50 states using measures of budget solvency, long-run solvency, service-level solvency, and trust fund solvency. Exhibit 4 reports their findings. Three states in the bottom five: Illinois, Kentucky, and New Jersey also rank in the bottom five for largest deficits in underfunded pension systems.

Despite techniques used to bypass regulations and legislation, the principles of balanced budget laws are well founded and stronger regulations seem to be helpful. The Urban Institute (2017) points to strong anti-deficit laws being associated with reduced spending, smaller deficits, more rapid spending adjustments during recessions, less debt, lower borrowing costs and higher surpluses. In addition, the Mercatus Center (2017) study cites unfunded pension liabilities as a major problem contributing to state budget difficulties stating,

"High deficits and debt obligation in the forms of unfunded pensions and healthcare benefits continue to drive each state into fiscal peril. Each holds tens, if not hundreds, of billions of dollars in unfunded liabilities-constituting a significant risk to taxpayers in both the short and long-term."

Based upon budget regulation as a case study, similar pension regulatory reform at the state legislative level could be considered by each state.

By reviewing the data on regulation surrounding balancing budgets, government regulation on a state-by-state basis could prove even more effective in dealing with the pension crisis and preventing it from getting worse in the future. Whether in support or opposition to the concept of DB plans, regulation could be helpful in dealing with the underfunding problem. States that ensure compliance with budget balancing legislation have much better results than those that allow ways around the intent of creating a balanced budget.

\section{Strategy for regulatory reform}

Although individual regulation and guidance must be adopted on a state-by-state basis, generally accepted pension funding guidance can be created on a national level. Advantages and disadvantages of DB plans should be considered when developing new policy. Even for states moving toward DC plans, the existing obligation must be effectively addressed. A collaborative method with the major professional organizations involved in recommending public pension guidelines would likely be one effective approach. 


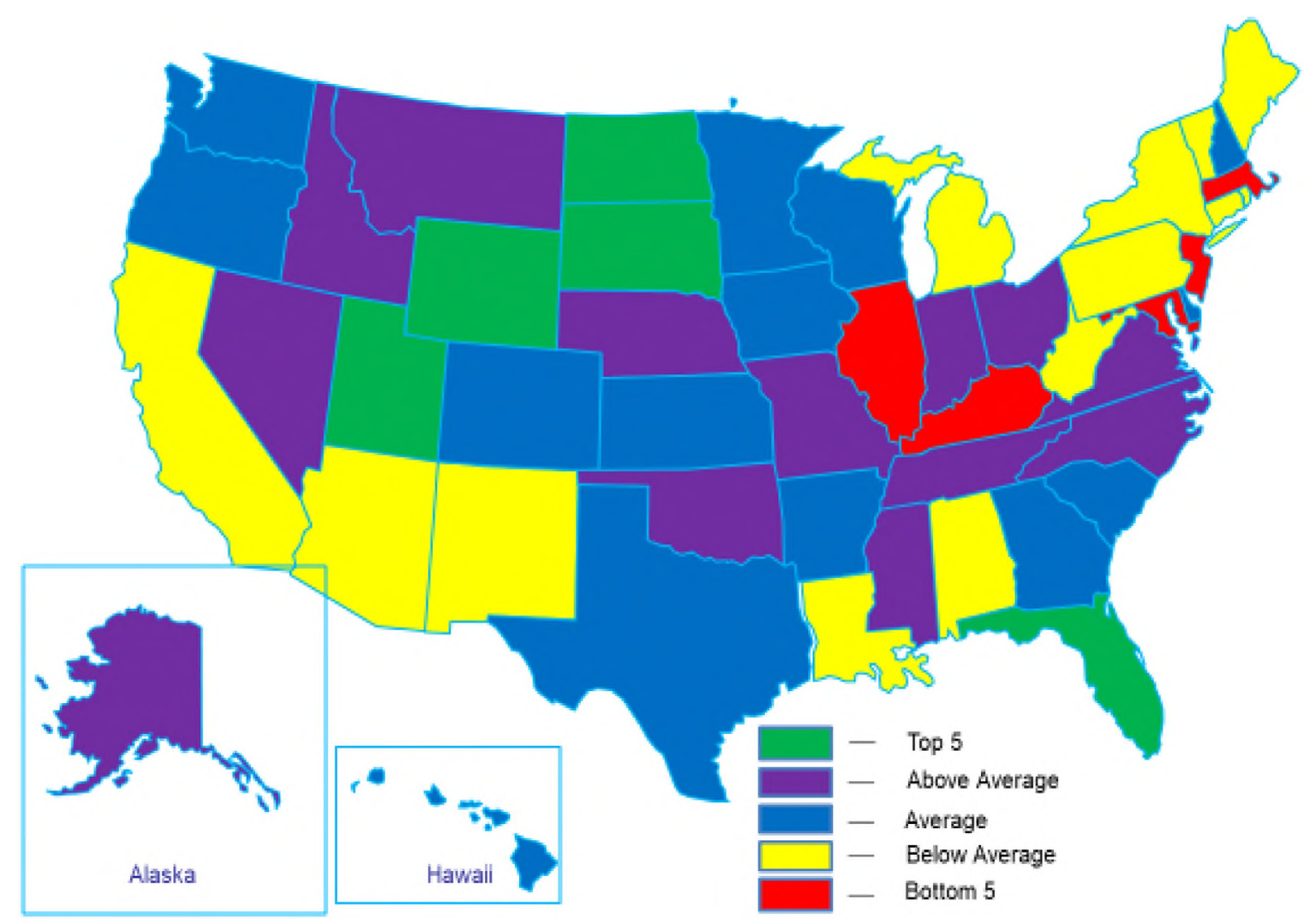

Exhibit 4. Fiscal Conditions Ranking.

Derived using data from Mercatus Center (Norcross, 201\%).

Organizations that should be considered for representation on such a committee are the Government Finance Officers Association (GFOA), the National Association of State Auditors, Comptrollers and Treasurers (NASACT), the National Governors Association (NGA), the National Conference of State Legislatures (NCSL), the National Association of State Budget Officers (NASBO), The National Association of College and University Business Officers (NACUBO), the National Association of State Retirement Administrators (NARSA), and the American Accounting Association (AAA). A role should also be considered for pension research institutes such as The Pew Charitable Trusts, the Center for Retirement Research, the Hoover Institute, the Urban Institute, and Mercatus Center. This joint group should use the following as a foundation for developing direction for regulation and guidelines for state managers, boards and public officials to adopt in each state:

\section{- Define fully funded and require all funds be funded at that} amount. The Government Accountability Office (2008) considers $80 \%$ funding of pension liabilities as sufficiently funded because public employers cannot go out of business like private sector counterparts, and state and local governments spread the liability over 20 or 30 years. In addition, it is difficult to accurately predict future economic events and numbers of government employees participating in any given plan and putting too much aside will place too much burden on the funds and taxpayers. Even with $80 \%$ being considered fully funded, 38 states currently fall below this fully funded mark. This, or a similarly supported rate, should be the amount recommended by the national board and approved by states as a legal requirement of funding.

- A generally accepted variable discount rate should be agreed to. A national variable discount rate should be researched and subsequently recommended for approval on a state by state basis. For example, a variable discount rate at $2.5 \%$ above the 10 -year treasury rate based upon current rates would yield a $5.3 \%$ annual expected rate of return. This rate offers a compromise between the current average of $7.6 \%$ being used and the $2.7 \%$ recommended rate of the Hoover Institute Study at Stanford University (Rauh, 2017). It also better incentivizes pension fund managers to adopt a less risky approach, allowing managers to diversify the portfolio with investments of lower volatility. This discount rate could be used as an overall guideline but would work better as a regulated percentage. If not specifically legally mandated, each fund should implement a discount rate based upon a disciplined approach as outlined under their investment policy.

- Standards for pension board governance and structure should be adopted. In a Sarbanes-Oxley type framework, pension boards need to take greater responsibility in the governance of pension plans. Instead of oversight being concentrated with plan management, board governance should include a separate investment committee. Direct reporting, hiring, and compensation of an independent investment advisor to the board is an excellent starting point. This investment committee would also be responsible for creating and approving the investment policy. Actuarial consultants should be considered for direct reporting to the board. In addition, discount rate determination should be reviewed and formally approved by the board if not regulated. Other areas of board management should include independent external reviews, expertise requirements, conflicts of interest checks, and auditor choice.

- Require a Board Passed Investment Policy that includes: - Goals, expectations, objectives, and guidelines; 


\begin{tabular}{|c|c|c|}
\hline Type & Metric & Measurement \\
\hline Solvency & Funded Ratio & $\frac{\text { Assets }}{\text { Accrued Pension Liability }}$ \\
\hline Solvency & Operating Margin & $\begin{array}{l}\text { Benefit Payments - Employer and } \\
\text { Employee Contributions }\end{array}$ \\
\hline Solvency & $\begin{array}{l}\text { Operating Cash } \\
\text { Flow }\end{array}$ & $\begin{array}{l}\text { Benefit Payments - Employer and } \\
\text { Employee Contributions }\end{array}$ \\
\hline Risk & Volatility & $\frac{\text { Equity and Alternative Investments }}{\text { Total Assets }}$ \\
\hline Risk & Safety & $\frac{\text { Fixed and Treasury Investments }}{\text { Total Assets }}$ \\
\hline Benefit & Employee Burden & Benefit Payments - Employee Contributions \\
\hline Benefit & Contribution Rate & Employee \% of Salary paid toward pension \\
\hline
\end{tabular}

Exhibit 5. Pension Fund Metrics.

- Requirements to perform risk analysis and set risk tolerance using tools and analytics such as efficient frontier evaluation which charts investments against risks;

- Set specific percentage ranges for individual investment categories such as US Large Cap, US Small Cap, International Developed, International Emerging, Diversified, Intermediate, Global Bonds, Hedge Funds, Alternatives, Short Term Treasuries;

- Analyze cash flow needs and adopt investment strategies based on the timing of cash flows;

- Segment investment pools by maturity and types of investments as follows - short-term (1-2 years), mid-range (3-8 years), intermediate ( $9-15$ years), long-term ( 16 plus years);

- The mandatory hiring of an investment advisor that is independent of investment managers;

- Create investment manager criteria;

- Set performance objectives;

- Develop a transparent, understandable reporting and communication plan; and

$\checkmark$ Perform an annual review of the investment policy.

- Creation of an independent oversight body should be explored on a national level. Although difficult to implement nationally due to the states' rights to regulate their public pension plans, a PCAOB-type organization to guide or at least recommend quality controls, ethics, independence, financial reporting and auditing rules could be beneficial. Although state and local government plans themselves can only be regulated on a stateby-state basis; investment advisors, dealers, and brokers can be regulated in a similar fashion as the Municipal Securities Rulemaking Board (MRSB). A body of this type can also promote transparency, create comprehensive databases of pension information, and set standards for investment advisors.

- Generally accepted metric development should occur. Currently, the only metric that is commonly referred to or used as a basis for decision making is the funded rate, which varies depending on the discount rate being used. The Pew Charitable
Trusts (2018) has offered a new measure this year: Operating Cash Flow. This metric is created by taking benefit payments minus employer and employee contributions and dividing by plan assets. It is a benchmark for the rate of return necessary to ensure that asset balances do not decline. Other measures for solvency, risk, and benefit should be developed. Exhibit 5 provides a sample of metrics for consideration.

- Fiscal emergency policies should be legislated for pension funds. Using several state budgetary laws as a design to build from, each state should enact regulation that: (1.) sets criteria to identify a funding crisis, (2.) outlines the steps that will be taken once an emergency is declared, and (3.) defines the appointment of a guiding authority while a plan is in crisis. For example, $60 \%$ to $80 \%$ funding of a plan could be deemed fiscal watch where the pension plan is given notice to improve. Below $60 \%$ funded could be declared a fiscal emergency. Once a plan is declared to be in fiscal emergency, laws, and regulations should specify that a state legislative committee, gubernatorial review board, or receiver be appointed to address the issue with a required strategy being adopted within a certain time period less than a year.

\section{- Additional actions to consider}

- Auditors of public pension plans, whether DB or DC, should be held to higher levels of accountability and exercise greater professional skepticism.

- States should review long-range funding of DB plans and budget accordingly.

- Benefit changes have already occurred in most states and some more may be needed, however, this shift from DB to $D C$ to solve funding issues should not be the first solution of choice as it has been.

$\checkmark$ An independent professional consulting team to review areas like management, procedures, and actuarial assumptions should be used in public retirement plans. Such an external team can also help implement policies not in place outlined above. 


\begin{tabular}{|l|l|}
\hline \multicolumn{1}{|c|}{ Strategy Area } & \multicolumn{1}{|c|}{ Type of Regulatory Reform } \\
\hline Funding Amount & Define fully funded at $80 \%$ \\
\hline Discount Rate & Variable rate tied to 10-year Treasury rate \\
\hline Board Governance & $\begin{array}{l}\text { Define responsibilities and create an investment } \\
\text { committee }\end{array}$ \\
\hline Investment Policy & $\begin{array}{l}\text { Require Board passed investment policy including } \\
\text { guidelines, risk asset classes, and investment advisor }\end{array}$ \\
\hline Independent Oversight & $\begin{array}{l}\text { Create a nationally recognized organization to provide } \\
\text { guidance and rules }\end{array}$ \\
\hline Metrics & $\begin{array}{l}\text { Define, compute, and benchmark key ratios and } \\
\text { measures }\end{array}$ \\
\hline Intervention triggers & $\begin{array}{l}\text { Declaration of fiscal emergency for funded levels below } \\
60 \%\end{array}$ \\
\hline Additional General & Audit, planning, consultation, leadership \\
\hline
\end{tabular}

Exhibit 6. Summary of Recommended Regulatory Pension Reform.

- Leadership, commitment, and fortitude must be exercised by managers, board members, and public officials.

Exhibit 6 summarizes regulatory reform proposals.

\section{Conclusion}

The recent pronouncements of the GASB have brought to the forefront the problems that public pension plans have been experiencing. Although the foundation of public pension plans has already begun to erode from both a solvency and employee benefits perspective, the human impact on the future wellbeing of public employees and retirees should be considered along with the societal impact. State lawmakers should begin consideration of enacting and enforcing pension legislation similar to that of existing balanced budget laws. National professional organizations should band together to present leadership solutions for pension fund managers and board members that include recommending a prudent discount rate, defining full funding, adopting a set of metrics, guiding pension board governance, and providing direction on investment policy. Advantages and disadvantages of DB plans, as well as the financial costs versus human impact should be carefully contemplated and included in the policy decision process. This paper offers specific recommendations on these matters to build policy and regulatory solutions upon.

\section{Acknowledgment}

Thanks to Dale Flesher and Mary Stone for their research assistance and contributions throughout the process. Special thanks to Gary Previts for his editorial input and guidance which have greatly enhanced this paper.

\section{References}

Barrett, K., \& Greene, R. (2011)., "Do states really balance their budgets?" Governing, October.

Bauman, M., \& Shaw, K. (2016). Harmonizing pension accounting: income statement effects of applying IAS19R to U.S. firms. Research in Accounting Regulation $28-1$.

Brainard, K., \& Brown, A. (2016). Significant reforms to state retirement systems. Na tional Association of State Retirement Administrators June.

DiSalvo, D. (2015). The linits on retrenchnent, the politics of pension reform. Manhattan Institute Civic Report, September.
Drucker, P. (19/6). The unseen revolution: how pension fund socialism came to America. Butterworth-HeinenndnI Publishers.

Eucalitto, C. (2013). Unbalanced: why state balanced budget requirements are not enough. American Legislative Exchange Council April.

Foltin, C. (201/). The role of federal regulation in state and local governments and the potential inpact of new reforms: an assessinent of the effectiventess of reporting, disclosure and funding. Research in Accounting Regulation, 29-1.

Foltin, C., Flesher, D., Previts, G., \& Stone, M. (2017)., "Accounting for the underfunding of public pensions - Escalating crisis or exaggerated concern?" Strategic Finarice, September, 2018.

Foltin, C., Flesher, D., Previts, G., \& Stone, M. (2018). State and local government pensions at the cross roads. CPA Journal April.

Fried, A., Davis-Friday, P., \& Davis, H. (2014). The impact of duration on management's discount rate choice. Research in Accounting Regulation, 26-2.

General Accountability Office. (2015). Most households approaching retirement have low savings. Report to the ranking members, subcommittee on primary health and retirement security. Committee on Health, Education, Labor, and Pensions May.

General Accountability Office (2008)., "State and local government pension plans Current structure and funded status," July 10th.

Hounes, R., Boylan, R., \& Crosby, W. (2012). On the value relevance of SFAS No. 158. Research in Accounting Regulation, 24

Institute for Truth in Accounting (2009)., "The truth about balanced budgets - - A fifty state study," February.

Merton, R. (2014). The crisis in retirement planning. Harvard Business Review July-August.

McGuinn, P. (2014). Pension politics: public employee retirement system reform in four states. Brown Center on Education Policy at Brookings February.

National Association of State Retirement Administrators (NARSA). (2017). NASRA is sue brief: State and local government spending on public employee retirement systerns March.

National Conference on Public Employee Retirement Systems (NCPERS). (2003). The evolution of public pension plans: Past, present, and future March.

National Conference of State Legislatures. (2010). State balanced budget provisions. Fiscal Brief October.

National Association of State Budget Officers. (2015). Budget processes in the states. Spring.

Norcross, E., \& Gonzalez, O. (2017). Ranking the states by fiscal condition. Mercatus Center, George Mason University.

Pew Charitable Trusts. (2018). The state pension funding Gap: 2016, investment shortfalls, insufficient contributions reduced funded levels for public worker retirement plans. Research Brief April.

Quinby, L., Sanzenbacher, G., \& Aubry, J.-P. (2018). How have pension cuts affected public sector competitiveness?. Center for Retirement Research at Boston College April.

Rauh, J. D. (201/). Hidden Debt, hidden Deficits. How Pension promises are consuning state and local budgets (2017 edition). The Hoover Institution May 15th.

Shaw, K. (2008). Revised pension rules and the cost of debt. Research in Accounting Regulation, 20.

Sgouros, T. (2017). Funding public pensions - Is Full funding a misguided goal?. University of California, Berkley, Haas Institute for a kair and Inclusive Society kebruary.

Stone, M. (1984). The pension accounting myth. Accounting Historians Journal Fall. 
Toossi, M, \& Torpey, E. (201/). Older workers: labor force trends and career options. United States Bureau of Labor Statistics May.

United States Department of Labor (2018)., "Private pension plan bulletin: historical tables and graphs," Contract DOLOPS14D0017, February.

United States Bureau of Labor Statistics. (2016). Defined contribution retirement plans: Who has them dild what do they cost. Beyond the Numbers, 5(17) Decentuber.
The United States, (1/89). Hirst congress, constitution, Anendment 10. Wilcox Volz, B., \& Ldermer, E. (201/). Legal settlements squeeze fees for US ermployee retirement plans. Financial Times March.

Wong, S. (2016). Public pension funds perform better when they keep politics at bay. Harvard Business Review digital version, July 19 th. 